\title{
Ciliate species diversity and host-parasitoid codiversification in Pseudocollinia infecting krill, with description of Pseudocollinia similis sp. nov.
}

\author{
D. H. Lynn ${ }^{1,4, *}$, J. Gómez-Gutiérrez ${ }^{2}$, M. C. Strüder-Kypke ${ }^{1,5}$, C. T. Shaw ${ }^{3}$ \\ ${ }^{1}$ Department of Integrative Biology, University of Guelph, Guelph, ON, N1G 2W1, Canada \\ ${ }^{2}$ Instituto Politécnico Nacional, Centro Interdisciplinario de Ciencias Marinas, Av. IPN s/n, A.P. 592, C.P. 23096, La Paz, \\ Baja California Sur, Mexico \\ ${ }^{3}$ Hatfield Marine Science Center, 2030 SE Marine Science Drive, Newport, Oregon 97365, USA \\ ${ }^{4}$ Present address: Department of Zoology, University of British Columbia, Vancouver, BC, V6T 1Z4, Canada \\ ${ }^{5}$ Present address: Department of Molecular and Cellular Biology, University of Guelph, Guelph, ON, N1G 2W1, Canada
}

\begin{abstract}
All parasitoid apostome ciliates infecting krill in the northeastern Pacific are currently assigned to the genus Pseudocollinia. Each krill specimen is apparently infected by only 1 Pseudocollinia species. We describe Pseudocollinia similis sp. nov., discovered infecting the krill Thysanoessa spinifera off Oregon, USA. Its protomite-tomite stage resembles that of $P$. beringensis, which infects $T$. inermis (type host species), T. longipes, and T. raschii females in the Bering Sea. These ciliates have similar numbers of somatic kineties (18-21 vs. 16-20) and typically have 3 oral kineties. Furthermore, these 2 apostomes are sister species on gene trees based on sequences of small subunit rRNA ( $0.06 \%$ difference) and cytochrome $c$ oxidase subunit 1 (cox1; $30 \%$ difference). $P$. brintoni and $P$. oregonensis are closely related as a separate group from $P$. similis and $P$. beringensis. The similar tree topologies based on the cox 1 sequences of 21 host krill individuals representing 6 krill species (Euphausia pacifica, Nyctiphanes simplex, T. inermis, T. longipes, T. raschii, and T. spinifera) and the apostomes isolated from these krill suggest host-parasitoid codiversification. However, this hypothesis was statistically rejected by an approximately unbiased test in which the host tree topology was used to model parasitoid evolution $(\mathrm{p} \leq 0.05)$.
\end{abstract}

KEY WORDS: Euphausiids · Apostomatida $\cdot$ Small subunit rRNA $\cdot$ SSUrRNA $\cdot$ Cytochrome $c$ oxidase subunit $1 \cdot \operatorname{cox} 1 \cdot$ Oregon

Resale or republication not permitted without written consent of the publisher

\section{INTRODUCTION}

Endoparasite apostome ciliates infecting the hemocoel of euphausiids were first reported by Capriulo \& Small (1986), who described a new species, Collinia beringensis, infecting the krill Thysanoessa inermis in the Bering Sea. Gómez-Gutiérrez et al. (2003) demonstrated that these ciliates are actually endoparasitoids and could have significant impacts on euphausiid populations (see also Capriulo et al. 1991). Further investigations of these ciliates in the context of population ecology of euphausiids of the eastern North Pacific Ocean involved extensive sampling of 7 euphausiid species. This has resulted in the description of 2 additional species of ciliates and an analysis that placed these 3 ciliate species in the new apostome genus Pseudocollinia (P. beringensis, P. oregonensis, and P. brintoni; Gómez-Gutiérrez et al. 2006, 2012). Mitochondrial cytochrome $c$ oxidase subunit 1 (cox1) and small subunit rRNA (SSU rRNA) gene sequences of the most recently described species $(P$. brintoni) and the type species $P$. beringensis 
demonstrated that they are apostomate ciliates (Gómez-Gutiérrez et al. 2012). Here, we present an additional contribution in this series describing the new species $P$. similis sp. nov., identified based on genetic evidence, but with no apparent taxonomically distinctive morphological features, collected on the Oregon (USA) coast from its type host T. spinifera. We redescribe $P$. oregonensis morphologically, and we report, for the first time, its mitochondrial cox1 and SSU rRNA gene sequences from its type host Euphausia pacifica collected from the Oregon coast. We also provide genetic sequence data for 11 additional $P$. beringensis isolates from $T$. raschii (9), T. inermis (1), and T. longipes (1) hosts and provide statistical and event-based analyses of the hypothesis that these 4 ciliate parasitoids have co-diversified with their 7 crustacean host species using $\operatorname{cox} 1$ sequences. The success of our investigations demonstrates that this endoparasitoid apostome-krill species assemblage is very likely more broadly distributed, suggesting that exploration of krill populations in other parts of the world's oceans will lead to the discovery of new apostome parasitoid species or the discovery of zoogeographical range extensions in the distribution of extant Pseudocollinia species, which have currently been studied only for the northeastern Pacific Ocean region (Bering Sea to Gulf of California).

\section{MATERIALS AND METHODS}

\section{Euphausiid collection}

Pseudocollinia oregonensis infecting Thysanoessa spinifera $(\mathrm{n}=29)$ and Euphausia pacifica $(\mathrm{n}=43)$ specimens, identified by the opaque to orange appearance (Fig. 1), were collected during 10 oceanographic cruises (2000-2002) on the continental shelf off the coasts of Washington, Oregon, and California, USA $\left(46^{\circ} 21^{\prime}\right.$ to $41^{\circ} 54^{\prime} \mathrm{N}, 124^{\circ} 19^{\prime}$ to $\left.125^{\circ} 01^{\prime} \mathrm{W}\right) . P$. beringensis infecting $T$. raschii $(\mathrm{n}=51), T$. inermis $(\mathrm{n}$ $=6)$, and $T$. longipes $(\mathrm{n}=4)$ were collected during 4 oceanographic cruises in the Bering Sea (April to May and June to July 2009, May and June 2010; $\left.55-62^{\circ} \mathrm{N}, 160-178^{\circ} \mathrm{W}\right)$. All specimens were collected using a $60 \mathrm{~cm}$ mouth diameter Bongo net or a $1 \mathrm{~m}^{2}$ MOCNESS net. Body length (back of the eye to the base of the telson) of specimens collected in the Bering Sea was measured and converted to total length using species-specific equations (Harvey et al. 2012). Measurements were made using a calibrated micrometer in a dissecting stereomicroscope. Specimens were preserved either in 96\% ethanol, Bouin's

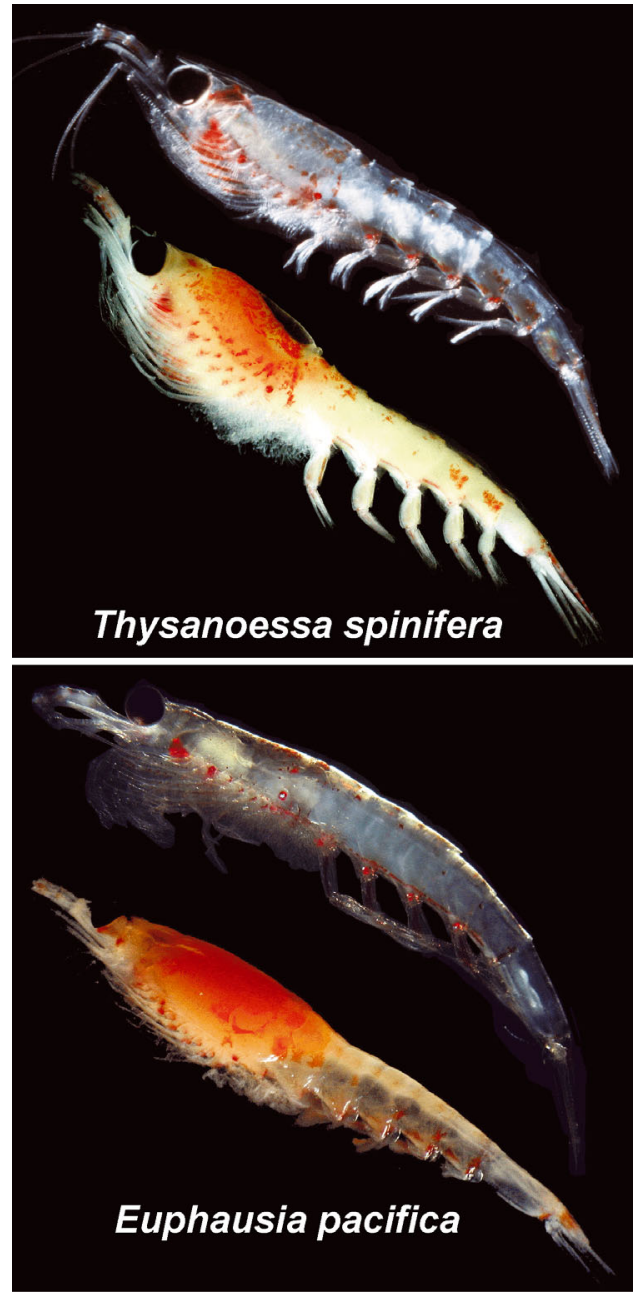

Fig. 1. Euphausiids Thysanoessa spinifera, host of Pseudocollinia similis sp. nov., and Euphausia pacifica, host of $P$. oregonensis, showing healthy specimens (upper example in each panel) and those in advanced infection stage with parasitoid ciliates of the genus Pseudocollinia (lower examples). Photograph of healthy T. spinifera taken by Phillip Colla; the other photographs were taken by Jaime GómezGutiérrez

fixative, or $4 \%$ formalin buffered with sodium borate, following the methods described by Gómez-Gutiérrez et al. $(2003,2006,2012)$. In the present study, only specimens preserved with $96 \%$ ethanol were used for correlative genetic and morphological analyses (both analyses done for ciliates derived from the same krill host specimen).

\section{Ciliate collection, preservation, and staining}

The cephalothorax of ethanol-preserved krill was opened and the masses of infecting ciliates were 
transferred into $1.5 \mathrm{ml}$ microcentrifuge tubes. The ciliates were rinsed with distilled water and stained by the quantitative protargol stain as described by Montagnes \& Lynn (1993).

\section{DNA sequence analysis of ciliate-krill mitochondrial cox1 gene and SSU rDNA}

Ciliates from 2 host specimens of T. spinifera, 3 host specimens of E. pacifica, 1 host specimen each of $T$. longipes and $T$. inermis, and 9 host specimens of $T$. raschii were also used for sequencing the SSU rDNA, ITS1-5.8S-ITS2-5'-LSU rDNA region, and cox1 genes, following the procedures described in detail by Gómez-Gutiérrez et al. (2012). The forward primer F388dT was used for $P$. oregonensis and the forward primer F298dT for $P$. beringensis and $P$. similis (Strüder-Kypke \& Lynn 2010). These Pseudocollinia sequences obtained from specimens collected in different regions (i.e. northeast Pacific including the Bering Sea, Washington, Oregon, and California coasts; Bahía Magdalena, located on the southwest coast of the Baja California peninsula, and Gulf of California, Mexico) were compared to each other and to previously published Pseudocollinia sequences ( $P$. brintoni isolated from Nyctiphanes simplex and $P$. beringensis isolated from $T$. inermis and T. raschii; Gómez-Gutiérrez et al. 2012). In the present study, we added the sequence from a T. longipes specimen, a new host species, collected in the Bering Sea. We also report the first genetic sequences of $P$. oregonensis obtained from $E$. pacifica collected from the Oregon coast.

The mitochondrial cox1 sequences of the host specimens were amplified, sequenced, and catalogued at the Biodiversity Institute of Ontario, Guelph, Canada. The gene sequences are available on BOLD and GenBank under accession numbers (HQ965947HQ965965).

Sequence analyses followed procedures described in detail by Gómez-Gutiérrez et al. (2012). An alignment of cox1 sequences was imported into MEGA ver. 5.2 (Tamura et al. 2011), while an alignment of SSU rDNA sequences was imported into the Dedicated Sequence Editor (De Rijk \& De Wachter 1993). Four different phylogenetic analyses-maximum likelihood (ML, using RaxML; Stamatakis et al. 2008), Bayesian inference (BI, using MrBayes; Ronquist \& Huelsenbeck 2003), maximum parsimony (MP, using PAUP 4.10; Swofford 2002), and neighbor joining (NJ, using PHYLIP ver. 3.6.9; Felsenstein 2009) - were performed on the alignments of SSU
rDNA and cox1 genes to construct trees as described by Gómez-Gutiérrez et al. (2012). The general time reversible model for nucleotide substitution, with gamma-distributed substitution rates and invariable sites, was identified as the best model for both genes using jModelTest ver. 2.1 (Guindon \& Gascuel 2003, Darriba et al. 2012). These parameters were used in ML and BI analyses. The data were re-sampled 500 (ML) and 1000 (MP, NJ) times. The MP analysis was performed with a random addition $(n=5)$ of the species and the tree bisection-reconnection branchswapping algorithm in effect.

\section{Test of codiversification hypothesis}

To test the hypothesis of codiversification (defined as the simultaneous diversification of 2 species lineages, especially of a parasite and its host), the host topology of the cox1 gene sequences was used as the constrained tree for the ciliate cox1 sequences using the approximately unbiased (AU) and ShimodairaHasegawa (SH) test as implemented in CONSEL ver. 01.j (Shimodaira \& Hasegawa 2001, Shimodaira 2002). For these tests, the constrained tree is taken as the null hypothesis. If the test demonstrates a statistically significant difference (i.e. $\mathrm{p} \leq 0.05$ ), then the null hypothesis is rejected and the constrained tree cannot be chosen as an explanation for the phylogenetic relationships.

We further analyzed the evolutionary associations among the euphausiid host species and the Pseudocollinia ciliate species with 2 reconciliation tools: CoRe-Pa ver. 0.5.1 (Merkle et al. 2010) and Jane ver. 4 (Conow et al. 2010). Phylogenetic trees inferred from the cox 1 sequences of (1) 1 representative of each krill host species and the corresponding endoparasitoid ciliates and (2) 1 representative each of the 6 krill host species and 1 representative each of the 4 endoparasitoid ciliate species were imported into CoRe-Pa and Jane, respectively, using the default options. One analysis was run with the default costs of each event as defined in the program (Jane: cospeciation $=0$, duplication $=1$, host switch $=$ 2 , loss of parasite $=1$, failure to diverge $=1$; CoRe-Pa: cospeciation $=0$, lineage sorting $=1$, duplication $=2$, host switch $=3$ ). The cost value of each event takes into account the likelihood of this event. Both programs employ the maximum parsimony principle to find a solution, and the resulting tree will show minimal total cost. In CoRe-Pa, we ran 100000 random cycles with and without root-to-root mapping enforced. A statistical test was performed in Jane over 
1000 cycles, with 500 randomizations in which random ciliate phylogenies were constructed (beta parameter $=-1$ ) in order to test whether the observed codiversifications are due to chance.

\section{RESULTS}

\section{Distribution patterns of krill in the Bering Sea}

We detected infections of krill by Pseudocollinia, presumably $P$. beringensis, in its type host species Thysanoessa inermis, and in 2 other abundant krill species, T. raschii and T. longipes. These krill hosts were distributed in either neritic ( $T$. raschii) or oceanic (T. inermis and T. longipes) waters (Fig. 2).

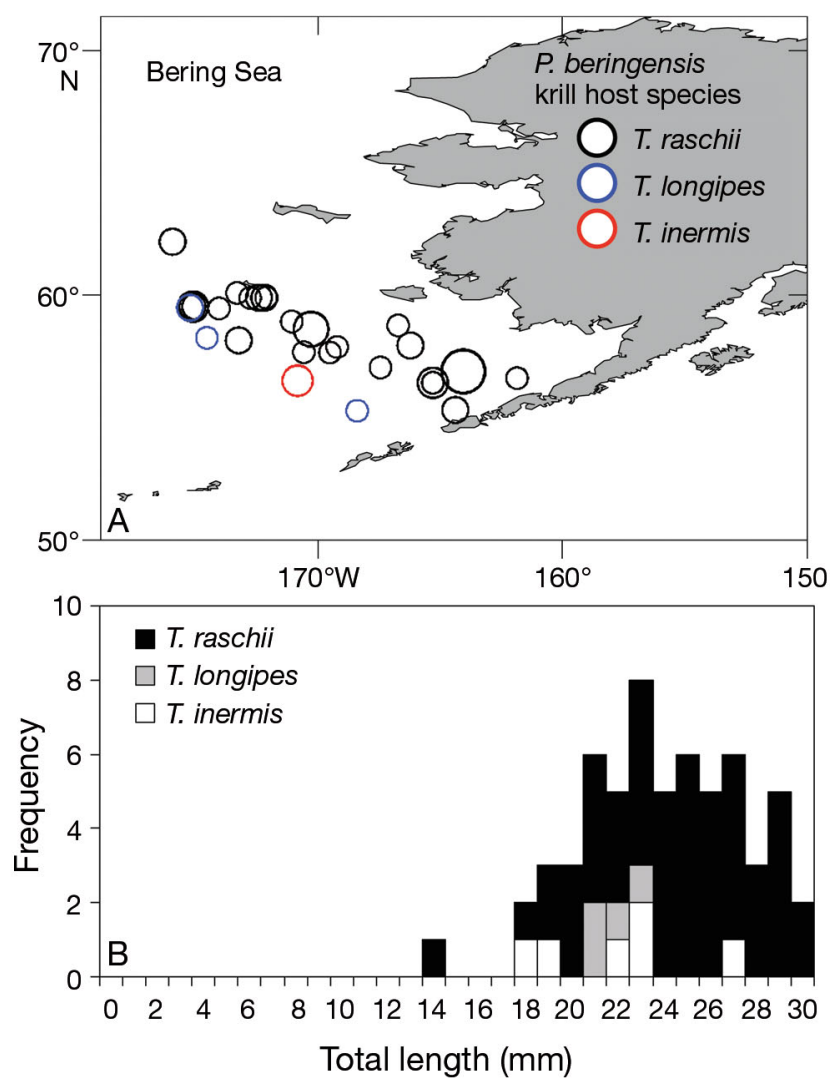

Fig. 2. Thysanoessa krill species in the Bering Sea infected with Pseudocollinia species. (A) Area of study and oceanographic stations where Thysanoessa species infected with $P$. beringensis were collected (2009-2010). The size of the circle is proportional to the number of infected specimens collected (range 1-6 krill). (B) Size-frequency distribution of infected individuals per krill species. Note that krill were not randomly sampled from the entire population

\section{Prevalences of Pseudocollinia spp.}

Prevalence of Pseudocollinia infection in the Oregon region has been estimated only for a few oceanographic stations. A total of 64 Euphausia pacifica specimens collected at 4 oceanographic stations yielded $10 \mathrm{E}$. pacifica infected with $P$. oregonensis (prevalence $=15.6 \%$ ). A total of 95 T. spinifera specimens collected from 7 oceanographic stations yielded $8 T$. spinifera infected with Pseudocollinia spp. (prevalence $=8.4 \%$; see Table 2 in Gómez-Gutiérrez et al. 2006). It is difficult to estimate prevalence of infected euphausiids since it is not easy to identify infected animals from preserved samples, and generally large catches of euphausiids preclude examining all individuals prior to preservation.

\section{Symptoms of infection by Pseudocollinia spp.}

Gómez-Gutiérrez et al. (2006) described the symptoms of infection of E. pacifica by P. oregonensis. The E. pacifica collected in the present study showed a similar etiology of infection, where all stages in the life cycle of $P$. oregonensis were observed, although only protomite-tomite stages have been stained so far (see below).

Healthy T. spinifera are typically transparent, but infected individuals show beige to orange coloration and the cephalothorax becomes swollen as the infection progresses (Fig. 1). The swimming pattern of the infected specimens is usually normal, but just before death they may swim in small circles or sink to the bottom of the incubation bottle, suggesting nervous system damage. The apostome endoparasitoid observed in the hemocoel of $T$. spinifera showed all the ciliate life-cycle stages described for the other Pseudocollinia species (i.e. phoront, trophont, tomont, and tomite in the host, and protomite-tomite and phoront outside the host).

\section{Protomite-tomite morphology of Pseudocollinia similis sp. nov.}

Protargol staining of ethanol-fixed $P$. similis $\mathrm{sp}$. nov. infecting $T$. spinifera revealed mostly ovoid protomite-tomite stages with a blunt anterior end (Figs. 3A-C \& 4A-C, Table 1). The cells were 44$57 \mu \mathrm{m}$ long and 26-38 $\mu \mathrm{m}$ wide (average $50.1 \times$ $32.1 \mu \mathrm{m}, \mathrm{n}=33$ ). They possessed a long and narrow macronucleus that stretched to almost the 

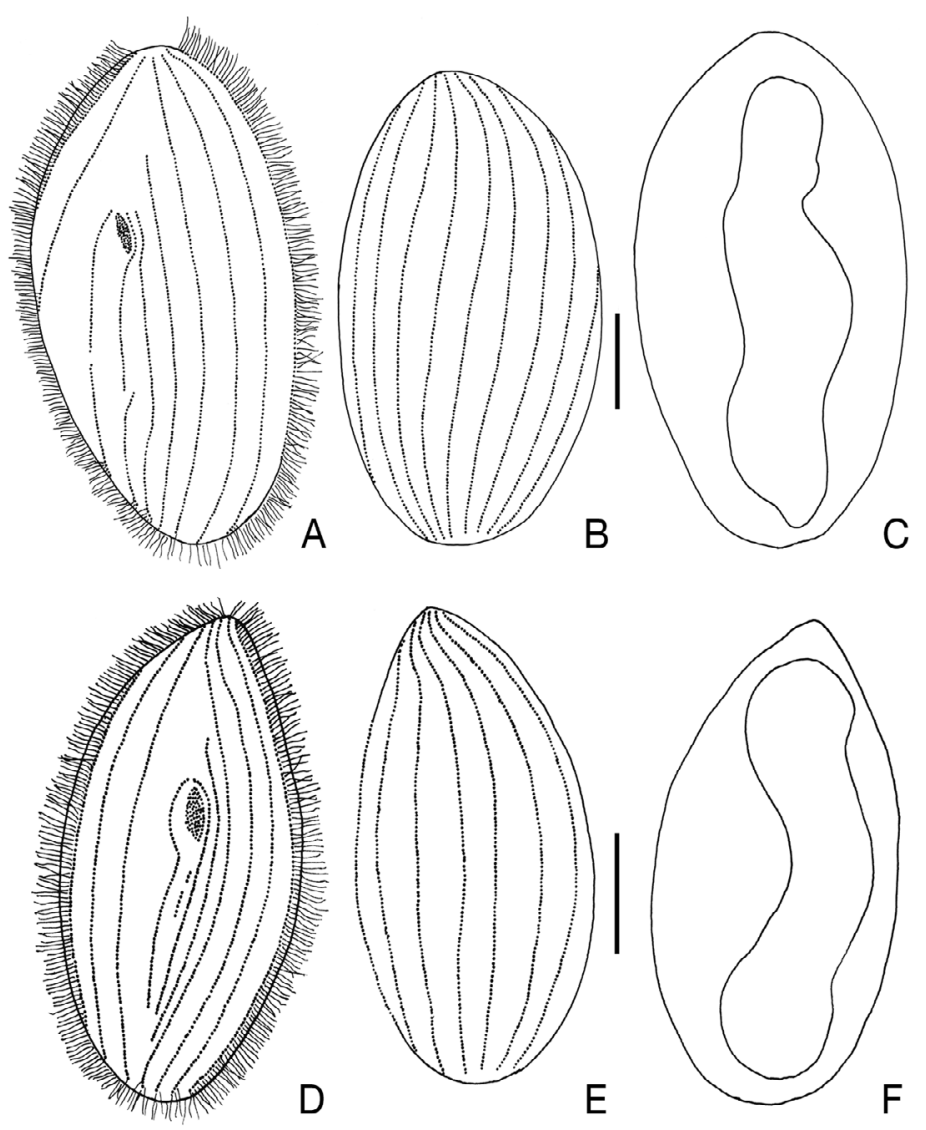

Fig. 3. Schematic drawings of (A-C) Pseudocollinia similis sp. nov. and (D-F) $P$. oregonensis. (A) Ventral view of the holotype of $P$. similis sp. nov., showing the dense ciliature and the dense field of oral kinetosomes on the left side of the oral cavity. There are 3 'oral' kineties: 1 on the right side of this oral field and 2 on the left side. (B) Dorsal view of the holotype. (C) Outline from another cell shows the size and shape of the macronucleus. (D) Ventral view of $P$. oregonensis showing the dense ciliature and the dense field of oral kinetosomes on the left side of the oral cavity. There are 2 'oral' kineties: 1 on the right side of this oral field and 1 on the left side. (E) Dorsal view of the cell in (D). (F) Outline of the cell in (D) showing the size and shape of the macronucleus. Scale bars $=10 \mu \mathrm{m}$

length of the cell (40-48 $\mu \mathrm{m}$ long, 5.6-11 $\mu \mathrm{m}$ wide, average $45 \times 8.5 \mu \mathrm{m}, \mathrm{n}=26$; Figs. $3 \mathrm{C} \& 4 \mathrm{C}) ; \mathrm{a}$ micronucleus was not observed. There were on average 20 kineties $(18-21, \mathrm{n}=33)$ that extended from pole to pole, except for 4 kineties. Three of these kineties, which might be called 'oral' kineties (or ciliary rows) and are numbered Kinety 1 (K1), Kinety $\mathrm{n}(\mathrm{Kn})$, and Kinety n-1 (Kn-1), curve around the oral cavity opening and terminate (Figs. 3A \& $4 \mathrm{~A}, \mathrm{~B})$. The fourth kinety, Kinety n-2, curves anteriorly and right above the oral cavity before terminating in a non-ciliated region anterior to the oral cavity (Figs. 3A \& 4A,B). The oral cavity, which is about $1 / 3$ the cell's length from the anterior end

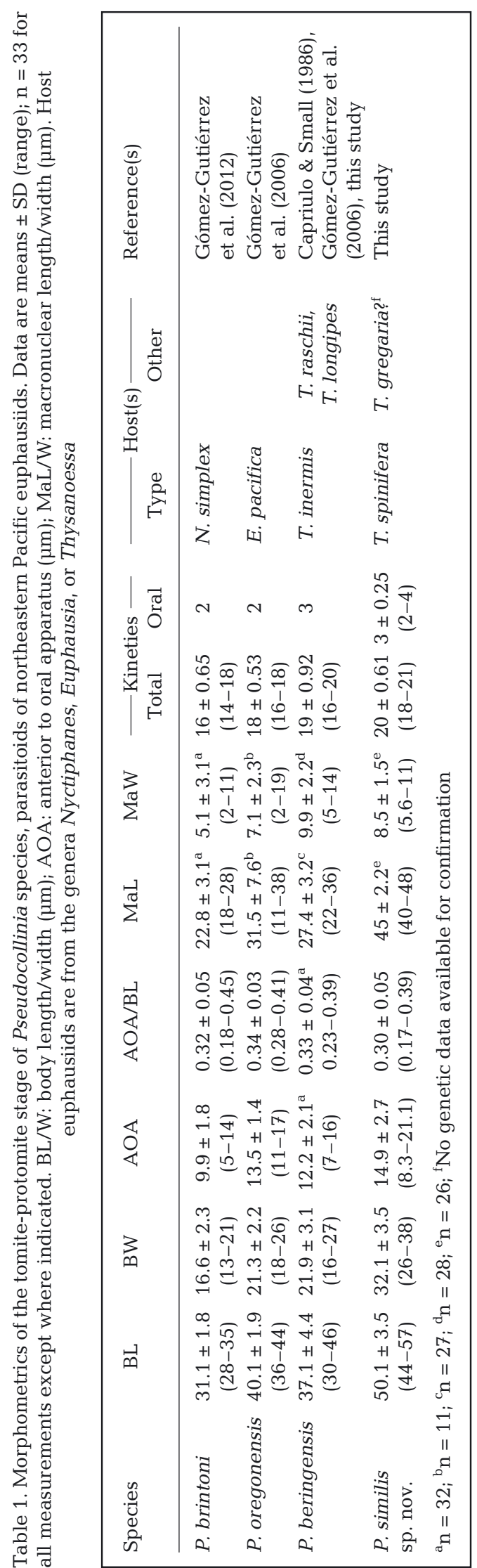




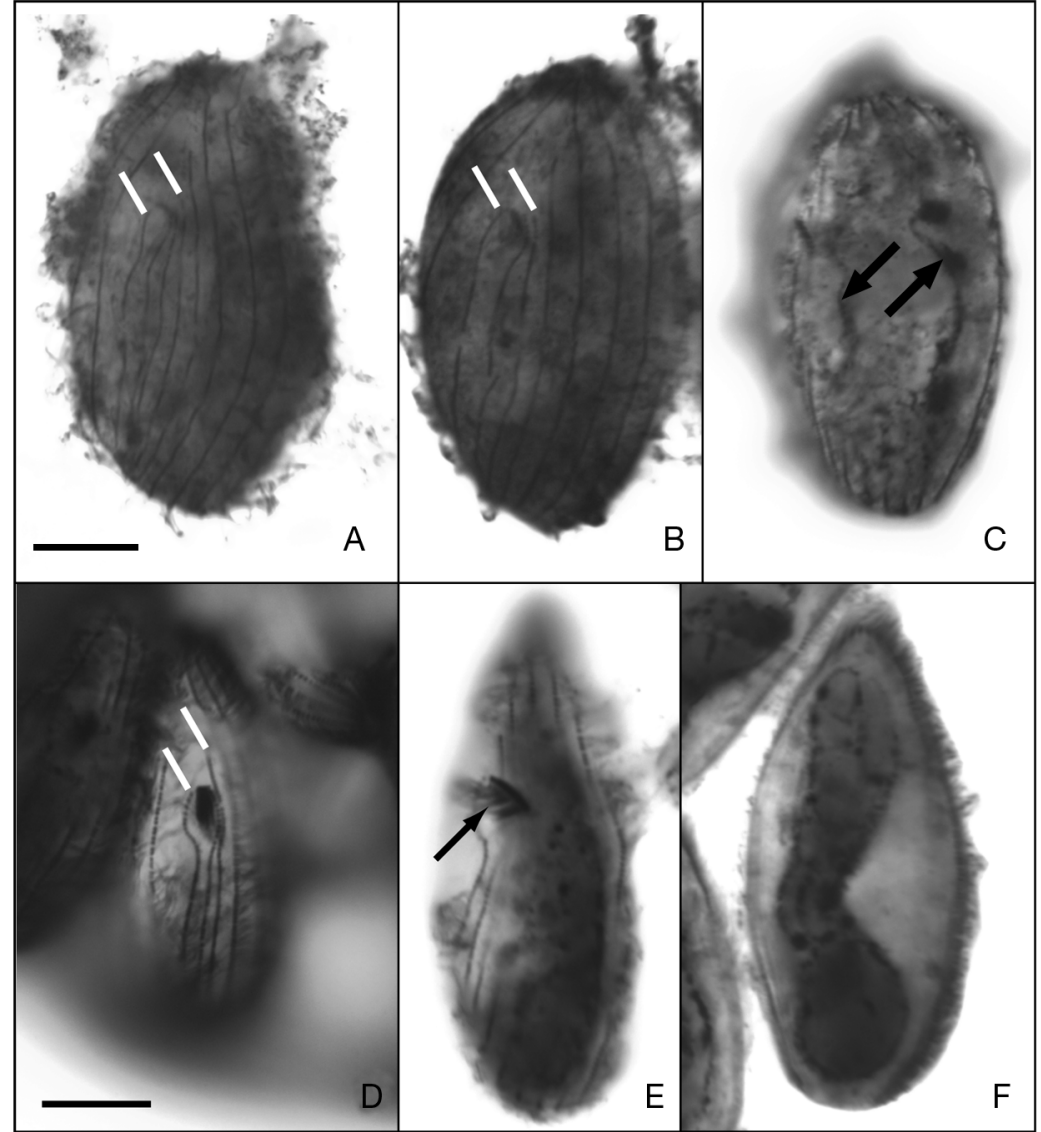

Fig. 4. Protargol-stained protomite-tomite stages of Pseudocollinia species. (A-C) P. similis sp. nov. that infects Thysanoessa spinifera. (A) Ventral view of specimen showing dense ciliature with Kinety 1, the rightmost 'oral' kinety (left white bar) and Kinety n-2, the leftmost 'oral' kinety (right white bar) indicated. Note that there are 4 'oral' kineties, Kinety 1, Kinety n, Kinety n-1, and Kinety n-2 in this specimen (cf. Fig. 3A). (B) Ventral view of holotype with the typical 3 'oral' kineties indicated (white bars). (C) Another specimen with the macronuclear envelope indicated (arrows). Scale bar for A-C $=10 \mu \mathrm{m}$. (D-F) $P$. oregonensis infecting Euphausia pacifica. (D) Ventral view with Kinety 1, the rightmost 'oral' kinety (left white bar) and Kinety n-2 (right white bar) indicated. This species has 2 'oral' kineties, Kinety 1 and Kinety $\mathrm{n}$ (see Fig. 4A). (E) Lateral view at sagittal plane showing cone-shaped oral cavity with cilia of the oral field extending outward (arrow). (F) Another specimen with the macronucleus shown. Scale bar for D-F $=10 \mu \mathrm{m}$

\section{Protomite-tomite morphology of $P$. oregonensis}

Protargol staining of ethanol-fixed $P$. oregonensis infecting E. pacifica revealed mostly ovoid protomitetomite stages with a pointed anterior end (Figs. 3D-F \& 4D-F, Table 1). The cells were 36-44 $\mu \mathrm{m}$ long and 18$26 \mu \mathrm{m}$ wide (average $40.1 \times 21.3 \mu \mathrm{m}$, $\mathrm{n}=33$ ). They possessed a long and narrow macronucleus that stretched to almost the length of the cell (11$38 \mu \mathrm{m}$ long by $2-19 \mu \mathrm{m}$ wide, average $31.5 \times 7.1 \mu \mathrm{m}, \mathrm{n}=11$; Figs. $3 \mathrm{~F} \&$ $4 \mathrm{~F}) ;$ a micronucleus was not observed. There were on average 18 kineties $(16-18, \mathrm{n}=33)$ that extended from pole to pole, except for 3 kineties (Figs. 3D \& 4D). Two of these kineties, which might be called 'oral' kineties (or ciliary rows) and are numbered Kinety 1 (K1) and Kinety n (Kn) curve around the oral cavity opening and terminate (Figs. 3D \& 4D). The third kinety, Kinety n-1, curves anteriorly and right above the oral cavity before terminating in a non-ciliated region anterior to the oral cavity (Figs. 3D \& $4 \mathrm{D})$. The oral cavity, which is about $1 / 3$ the cell's length from the anterior end (Table 1), appears to be coneshaped and lined on its left wall with a dense field of ciliated kinetosomes or basal bodies (Figs. 3D \& 4D,E). Morphological measurements were made on ciliates from 2 E. pacifica hosts (specimen nos. 28 and 30); the ciliates of a third E. pacifica host (no. 31), were confirmed genetically as $P$. oregonensis (see below).

\section{Gene sequences of Pseudocollinia species}

its left wall with a dense field of ciliated kinetosomes or basal bodies (Figs. 3A \& 4A,B). Measurements were made on ciliates from a $T$. spinifera host (specimen no. 29), as the ciliates from the other host (specimen no. 2), which were confirmed genetically as $P$. similis sp. nov. (see below), were not well stained. Nevertheless, a few well-stained individuals from this other host showed identical morphological characteristics.
The complete SSU rDNA gene sequence of $P$. similis sp. nov. is 1746 nucleotides (nt) in length, has a GC content of $41 \%$, and is identical for both isolates. The ITS1, 5.8S rRNA, ITS2, and partial large subunit (LSU) rRNA gene sequences were obtained as well, and like the SSU rRNA, they are identical for both $P$. similis isolates. 
The complete SSU rDNA gene sequence of $P$. oregonensis is $1746 \mathrm{nt}$ in length and has a GC content of $41 \%$. It is almost identical among the 3 isolates (difference of $3 \mathrm{nt}$ ). The ITS1, 5.8S rRNA, ITS2, and partial LSU rRNA gene sequences of the isolates of $P$. oregonensis are identical.

The divergence between the SSU rDNA gene sequences of these 2 species is $0.6 \%$, while they show $3.2 \%$ divergence in their ITS and 5.8S gene regions. All Pseudocollinia sequences have been submitted to GenBank under accession numbers HQ591468HQ591488 (see also Gómez-Gutiérrez et al. 2012).

The mitochondrial cox1 genes of $P$. similis sp. nov. and $P$. oregonensis include inserts that are 458 and 449 nt long, respectively. The inserts are typical for ciliates but they are considerably longer than those of other ciliate species analyzed so far (Strüder-Kypke \& Lynn 2010, Gómez-Gutiérrez et al. 2012). The lengths of the partial cox1 gene sequences are 852 to 1012 nt due to the different forward primers used. As in all ciliates, the GC content is low at $29-30 \%$. The 2 isolates of P. similis show $0.1 \%$ divergence, while the 2 isolates of $P$. oregonensis show $16 \%$ divergence. Isolates of the 2 species were $50 \%$ divergent, mainly due to considerable differences in the extremely variable insert regions. All Pseudocollinia cox1 sequences have been submitted to GenBank under accession numbers HQ591489-HQ591507.

The phylogenetic analyses of the SSU rDNA sequences place the 4 Pseudocollinia species in a well-supported monophyletic clade with other apostome ciliates. Pseudocollinia species are most closely related to Fusiforma themisticola, recently described as a parasitoid in the hemocoel of the zooplanktonic hyperiid amphipod Themisto libelulla collected in the Canadian Beaufort Sea (Arctic Ocean) (Chantangsi et al. 2013). Fusiforma along with Pseudocollinia species are currently assigned to the family Pseudocolliniidae, which is in turn closely related to other known histophagous parasitoid apostome ciliates that infect other crustaceans like decapods and copepods (Fig. 5). P. similis sp. nov. and P. oregonensis are quite well separated in the tree inferred from SSU rDNA sequences, with $P$. oregonensis basal in the radiation next to $P$. brintoni (Fig. 5). A distinct genetic distance of 0.5 separates them in the tree inferred from cox1 gene sequences and robustly shows that $P$. similis sp. nov. (temperate) and $P$. beringensis (Arctic) are sister species, while P. oregonensis (temperate) is the sister species of $P$. brintoni (subtropical), suggesting a latitudinal zoogeographic cline of the krill hosts (Fig. 6).

\section{Codiversification of Pseudocollinia species and their euphausiid hosts}

The topology of the cox1 gene tree of the euphausiid hosts, generated by NJ analysis, was used to determine whether it might explain the diversification of the 4 currently known Pseudocollinia species in the northeast Pacific Ocean (Figs. $6 \&$ 7). The multiple specimens of the 3 genera of euphausiids (Nyctiphanes, Euphausia, and Thysanoessa) form monophyletic clades, while the monophyly of multiple species in the genus Thysanoessa is robustly confirmed in those species sampled more than once. When comparing the Pseudocollinia and host phylogenetic trees, the branch leading to the 2 isolates of $P$. similis sp. nov. is basal among Pseudocollinia isolated from Thysanoessa spp., while T. spinifera, the type host for $P$. similis, is not basal in the Thysanoessa radiation (Figs. $6 \& 7$ ). It is likely that this difference in topology leads to the statistical rejection of absolute codiversification of these endoparasitoid ciliates and their krill hosts (i.e. AU, p =0.015; $\mathrm{SH}$, $\mathrm{p}=0.022$ ).

The event-based codiversification analyses of host and ciliates in CoRe-Pa and Jane models, with default cost parameters, obtained 2 trees and 1 tree, respectively (Fig. 7a). Both programs differentiate between host-dependent events (co-speciation, lineage sorting) and host-independent events (duplication, duplication with host switch, failure to diverge). Co-speciation defines the event that host and parasite speciate simultaneously. Lineage sorting (referred to as 'Loss' in Jane) happens when, after a host speciation, the parasite species remains on only 1 of the new host species. Duplication means that only the parasite species speciates, and both child species of the parasite are associated with the same host as the parent species. Duplication with host switch is counted as 1 event in which the parasite speciates and 1 of the child species immediately switches to a new host species (Charleston 1998, Keller-Schmidt et al. 2011). Failure to diverge (only in Jane) is the case if the host speciates and the parasite remains associated with both new host species. Depending on the input tree ( 6 and 4 ciliate species, respectively), the computed trees show 2 different solutions. CoRe-Pa does not allow multiple host species per parasite species, so the second tree input was only calculated with Jane. The first tree (6 hosts, 6 ciliates) reconstructed with both programs shows 3 codiversification events, 1 loss, no duplications, and 2 host switches (3-1-0-2), with a total cost of 5. The statistical test with Jane showed that only $18 \%$ of the 


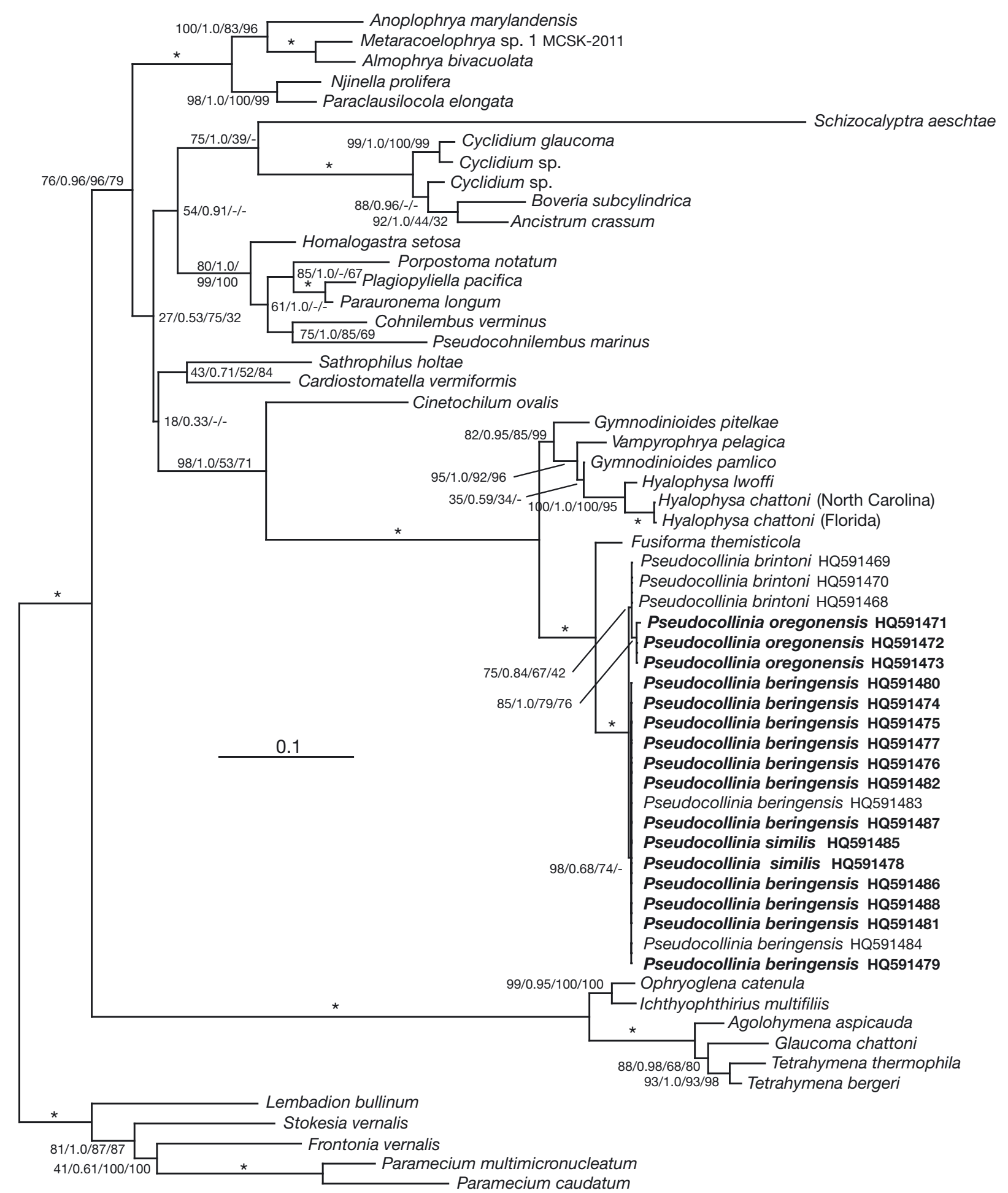

Fig. 5. Ciliate phylogenetic tree inferred from small subunit (SSU) rDNA gene sequences, computed with RAxML (Stamatakis et al. 2008), based on the general time reversible model with gamma distribution and an estimate of invariable sites. The first number at the nodes represents the bootstrap support for RAxML (maximum likelihood, ML); the second number represents posterior probability values of the Bayesian inference (BI) analysis; and the third and fourth numbers represent bootstrap values for maximum parsimony (MP) and neighbor joining (NJ), respectively. New sequences for Pseudocollinia spp. indicated in bold show unambiguously that they cluster with the other described species of the genus. Asterisks indicate full support in all analyses and dashes indicate support values $<30 \%$. Scale bar $=10$ substitutions per 100 nucleotides 


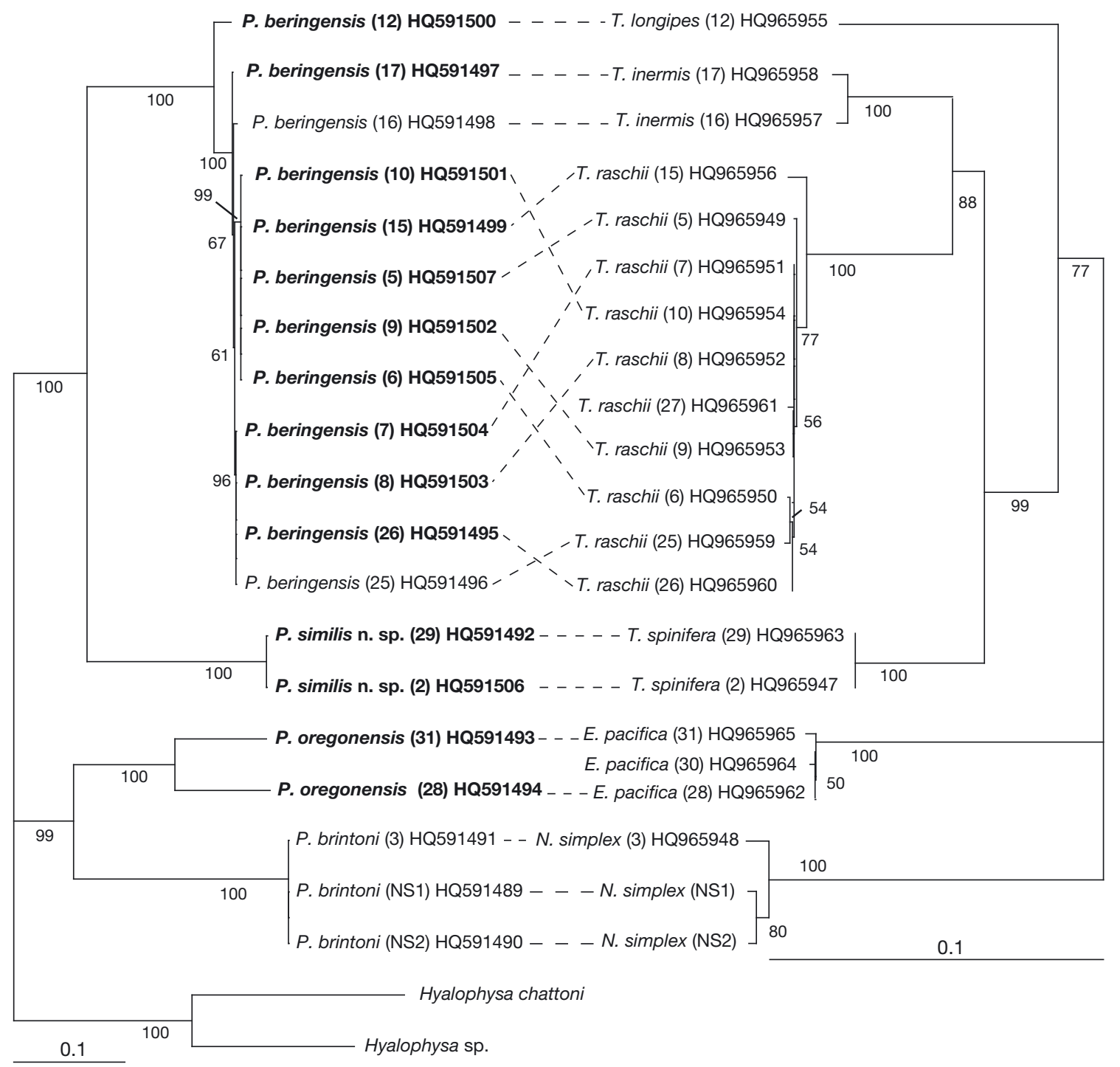

Fig. 6. Phylogenetic trees inferred from mitochondrial cytochrome $c$ oxidase subunit 1 (cox1) gene sequences, computed with neighbor joining ( $N J_{i}$ Saitou \& Nei 1987), based on the Kimura 2-parameter model (Kimura 1980). The left hand tree shows relationships among the apostome parasitoid ciliates of the genus Pseudocollinia while the right hand tree shows relationships among their krill hosts. The number at the nodes represents the bootstrap support for NJ. New sequences for Pseudocollinia spp. indicated in bold show unambiguously that these specimens can be assigned to this genus. $P$. similis sp. nov. and $P$. oregonensis are separated by $50 \%$ sequence divergence. Scale bars = 10 substitutions per 100 nucleotides

random trees showed a better (lower) total cost value than the minimum cost tree shown in Fig. 7a, suggesting that the retrieved codiversifications were not a random result. Enforced root-to-root mapping in CoRe-Pa resulted in a tree with 1 additional loss (3-2$0-2)$. The second tree (6 hosts, 4 ciliates) reconstructed with Jane shows 2 codiversification events, no loss, no duplication, 1 host switch, and 2 failureto-diverge events (2-0-0-1-2), with a total cost of 4 . The statistical test with Jane showed that only $4.6 \%$ of the random trees had a better (lower) total cost value than the minimum cost tree shown in Fig. $7 \mathrm{~b}$.

\section{DISCUSSION}

\section{Comparing morphology and genetic diversity of Pseudocollinia endoparasitoid phases}

With the discovery of $P$. similis sp. nov. there are now 4 species in this genus of parasitoids that infect euphausiids of the northeast Pacific Ocean (Capriulo \& Small 1986, Capriulo et al. 1991, Gómez-Gutiérrez et al. 2003, 2006, 2012). Recently, the family Pseudocolliniidae was established to include what were then 3 known species in the type genus Pseudocollinia and 

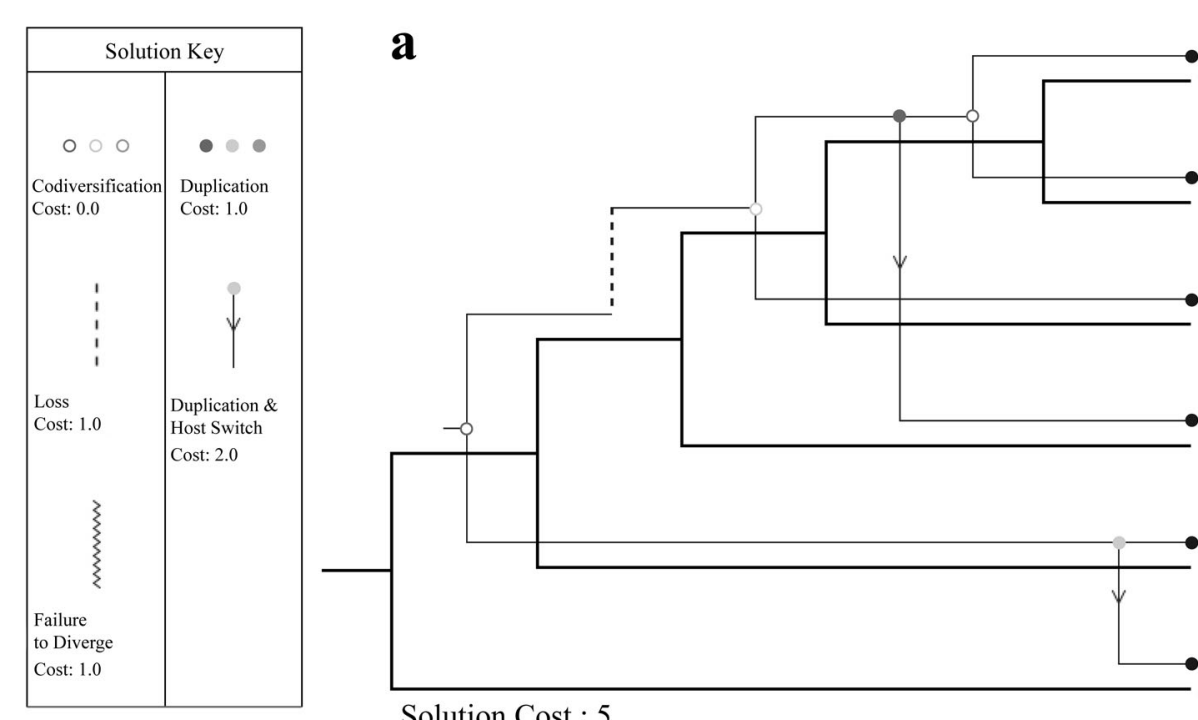

Solution Cost : 5

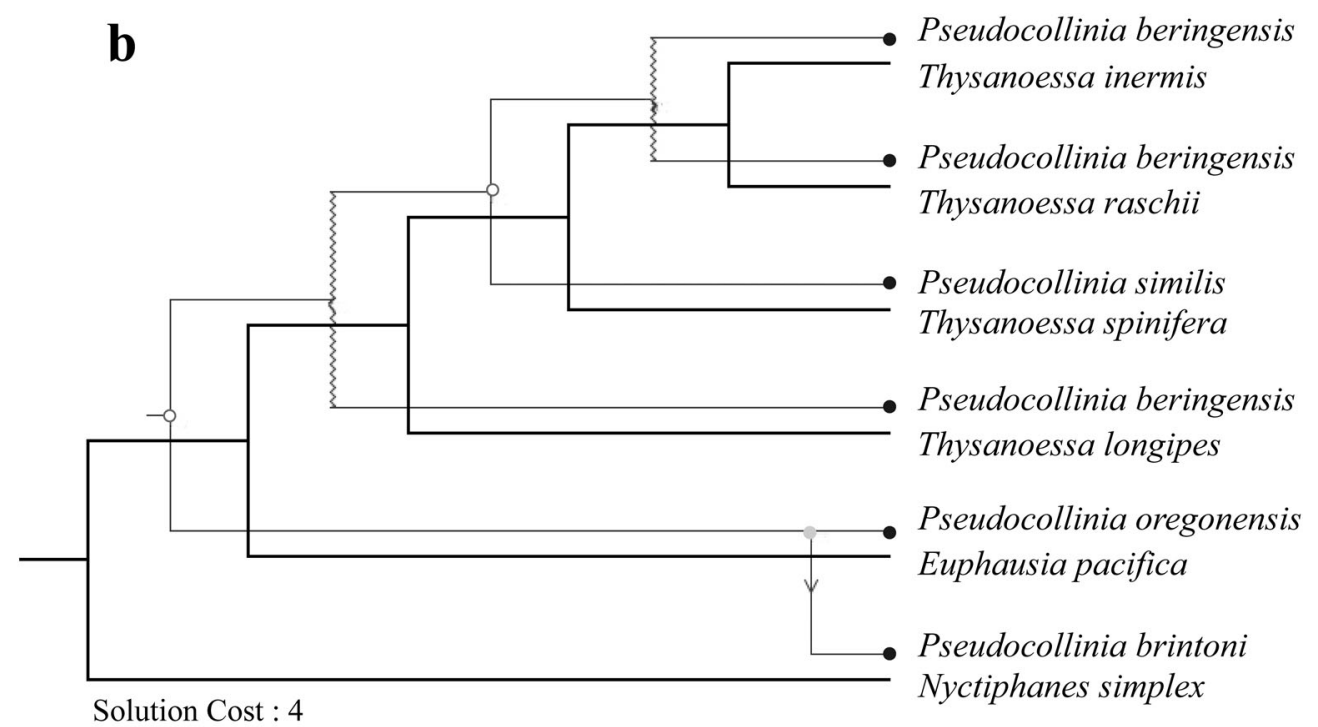

Pseudocollinia beringensis

Thysanoessa inermis

Pseudocollinia beringensis

Thysanoessa raschii

- Pseudocollinia similis

Thysanoessa spinifera

Pseudocollinia beringensis

Thysanoessa longipes

Pseudocollinia oregonensis

Euphausia pacifica

- Pseudocollinia brintoni Nyctiphanes simplex

Pseudocollinia beringensis

Pseudocollinia beringensis

Pseudocollinia similis

Pseudocollinia beringensis

Fig. 7. The preferred reconstruction obtained by Jane analysis with default event costs. (a) Minimum cost tree with 6 ciliate species and 6 host species showing 3 codiversification events, 2 duplications with host switch, and 1 loss (3-1-0-2-0). (b) Min-
imum cost tree with 4 ciliate species and 6 host species showing 2 codiversification events, 1 duplication with host switch, and

2 failure to diverge events (2-0-0-1-2). The host tree topology is shown in black and the parasitoid tree topology in gray

Fusiforma themisticola, a newly discovered apostome that infects the hyperiid amphipod Themisto libellula (Chantangsi et al. 2013). Gómez-Gutiérrez et al. (2012) reexamined the type slide of $P$. oregonensis and determined that, while it could be placed in the genus Pseudocollinia, higher-quality protargol stains would be useful to characterize the protomite-tomite stage more fully. We have now provided this morphological and genetic characterization along with the characterization of $P$. similis sp. nov. (Table 1).

Gómez-Gutiérrez et al. (2006) provided characterization of the tomites of $P$. oregonensis, based on enu- meration of features from scanning electron micrographs, staining with protargol, and cells in different stages of palintomy stained with hematoxylin and counterstained with Fast Green. The ranges that they provided for tomite stages obtained from the type host Euphausia pacifica overlap the ranges of our protargol-stained specimens from the same krill host species: 19-37 $\mu \mathrm{m}$ long $\times 15-30 \mu \mathrm{m}$ wide (GómezGutiérrez et al. 2006) vs. 36-44 $\mu \mathrm{m}$ long $\times 18-26 \mu \mathrm{m}$ wide (Table 1); and total kineties of 16 (GómezGutiérrez et al. 2006) vs. 16-18 (Table 1). Furthermore, like the original description of $P$. oregonensis, 
we have also observed in our samples that the ovoid tomite with a pointed anterior end (cf. Fig. 5A in Gómez-Gutiérrez et al. 2006) and a cone-shaped oral cavity are features of this species (cf. Fig. 5I in Gómez-Gutiérrez et al. 2012). Thus, we assign this recent isolate from $E$. pacifica, the type host of $P$. oregonensis, to this species and provide a revised morphological characterization (see below) and genetically characterize the species using the SSU rDNA and cox1 gene sequences.

Genetic characterization of ciliate species is becoming more common since extensive comparative molecular genetic research on the biological species of Tetrahymena (Kher et al. 2011) and Paramecium (Strüder-Kypke \& Lynn 2010, Przyboś et al. 2013) using the mitochondrial cox1 gene has demonstrated significant interspecific variation. For example, Kher et al. (2011) concluded that a >5\% difference in cox1 identifies different biological species of Tetrahymena, while Strüder-Kypke \& Lynn (2010) concluded that this criterion rises to $>20 \%$ for biological species of Paramecium. Biological species of Tetrahymena can have identical gene sequences for SSU rRNA, and so it is best to avoid this gene as a criterion for genetic species identification for taxonomic purposes (Strüder-Kypke \& Lynn 2010). While we know nothing about the sexual reproductive biology of Pseudocollinia species, we believe that choosing a $20 \%$ criterion for differences in the cox1 barcode should conservatively support identification of genetic species with taxonomic value.

We provide a comparative table to demonstrate the similarities and differences among the 4 Pseudocollinia species identified to date from 6 euphausiid species distributed in the northeast Pacific (Table 1). It is virtually impossible to unambiguously identify these apparently cryptic species based only on morphology, as almost all morphometric characteristics of the tomites overlap, although $P$. beringensis and $P$. brintoni do not overlap in number of kineties, geographic distribution, or host species. Nevertheless, genetic characterization, especially using the cox1 gene sequences, clearly separated these 4 parasitoid species: $P$. similis sp. nov. from Thysanoessa spinifera differs from $P$. oregonensis from E. pacifica by $50 \%$ based on the cox1 gene barcode (Fig. 6). Furthermore, our data indicate that there are 2 sets of sister species characterized by different numbers of oral kineties. $P$. brintoni and $P$. oregonensis invariably have 2 oral kineties as tomites and are genetically separated using the cox 1 gene barcode by $35 \%$ (Fig. 6). They also parasitize different genera of euphausi- ids: $P$. brintoni infects Nyctiphanes simplex and $P$. oregonensis infects E. pacifica (Fig. 6, Table 1).

$P$. beringensis and $P$. similis sp. nov. typically have 3 oral kineties as tomites and are genetically separated by $30 \%$ using the Cox 1 gene barcode (Fig. 6). These 2 species parasitize at least 4 species of the genus Thysanoessa: $P$. beringensis infects $T$. inermis, T. longipes, and $T$. raschii while $P$. similis infects T. spinifera (Fig. 6, Table 1). Nevertheless, P. similis sp. nov. has the most variable numbers of oral kineties. This appears to be correlated with breaks in these kineties in the cell equatorial region (Fig. 3A), suggesting a mechanism whereby the anterior fragment extends posteriorly and the posterior fragment extends anteriorly to increase the number of oral kineties by 1 .

\section{Codiversification of Pseudocollinia species and their euphausiid hosts}

Gómez-Gutiérrez et al. (2006) claimed that $P$. oregonensis also infected Euphausia pacifica, T. spinifera, and T. gregaria on the Oregon coast (Table 1, Gómez-Gutiérrez et al. 2006). We now conclude, based on genetic evidence, that the Pseudocollinia species infecting T. spinifera is a different species, viz. $P$. similis sp. nov., while the genetic species $P$. oregonensis is assigned to those ciliates isolated from the type host E. pacifica, as defined by GómezGutiérrez et al. (2006). We have been unable to collect additional infected specimens of $T$. gregaria to obtain gene sequences of its ciliate parasitoid, and so cannot identify with certainty the Pseudocollinia species that infects this euphausiid species. Further genetic studies could determine whether $P$. oregonensis can indeed infect other krill hosts in the diverse northeast Pacific or even in other regions of the world.

Our inferred phylogenetic tree of the euphausiid species is very limited in the number of species and lacks an outgroup. While the relationships among species of the genus Thysanoessa seem well resolved and the specimens of E. pacifica and N. simplex can be unambiguously identified as conspecific, the relationships between the 3 genera are not clear. Jarman (2001) analyzed nuclear rDNA of several krill genera and D'Amato et al. (2008) inferred a phylogenetic tree from mitochondrial SSU rRNA and cox1 genes. The nuclear genes grouped Euphausia and $\mathrm{Nyc}_{\mathrm{C}}$ tiphanes as sister genera and basal to Thysanoessa, while the mitochondrial SSU rDNA genes placed Euphausia in the basal position of the 3 genera. 
Parasites often codiversify or coevolve with their hosts, and recently gene sequences and inferred tree topologies have been used to test these hypotheses of codiversification (Johnson et al. 2004, Kuo et al. 2008, Cruaud et al. 2012, Rosenblueth et al. 2012, Du Toit et al. 2013). While event-based reconciliation tools show some codiversification of Pseudocollinia species with their host euphausiids, the AU/SH tests rejected absolute codiversification. It would appear that $P$. beringensis, which apparently has broader host infection capabilities than the other species of Pseudocollinia, can infect T. longipes, which is a basal species in the Thysanoessa radiation, while the $P$. beringensis isolate from $T$. longipes clusters robustly with all other $P$. beringensis isolates, albeit basal in this clade (Fig. 6). P. similis and P. beringensis, which diverge significantly in their cox1 gene sequences $(30 \%)$, show little divergence in their SSU rDNA and ITS1-5.8S-ITS2-5'-LSU rDNA sequences $(0.06 \%$ and $1.4 \%)$. This may indicate a very recent speciation, which is not yet reflected in the more highly conserved genes.

Kulka \& Corey (1984) discovered protozoans, identified as sporozoans, infecting $T$. inermis (prevalence of $2.8 \%$ ) in the Bay of Fundy, east coast of Canada (Atlantic Ocean). Our re-examination of the published micrographs in this report, in light of our morphological and genetic work on Pacific krill, leads us to believe that the external and internal features of the cells, their size, and the mode of palintomic cell division are similar to those features of Pseudocollinia species described from Pacific krill. Possibly Kulka \& Corey (1984) actually first discovered $P$. beringensis, which was formally described $2 \mathrm{yr}$ later from the same krill host species, T. inermis, in the Bering Sea (Capriulo \& Small 1986). If true, this greatly extends the current known biogeographic distribution range of Pseudocollinia to the northwest Atlantic Ocean, and suggests the possibility that Pseudocollinia species may infect other krill species worldwide.

\section{Taxonomic summary of Pseudocollinia oregonensis and $P$. similis sp. nov.}

Subclass: Apostomatia Chatton \& Lwoff, 1928

Order: Apostomatida Chatton \& Lwoff, 1928

Family: Pseudocolliniidae Chantangsi, Lynn, Rueckert, Prokopowicz, Panha, \& Leander, 2013

Genus: Pseudocollinia Gómez-Gutiérrez, StrüderKypke, Lynn, Shaw, Aguilar-Méndez, López-Cortés, Martínez-Gómez, \& Robinson, 2012

\section{Pseudocollinia oregonensis Gómez-Gutiérrez, Peterson, \& Morado, 2006}

Diagnosis: All life cycle stages possess 16-18 somatic kineties; tomite stage, ovoid with pointed anterior end; oral cavity bordered by 2 'oral' kineties; infecting a broadcast-spawning euphausiid with subarctic biogeographic distribution.

Type host: Euphausia pacifica Hansen, 1911

Type location: Northeast Pacific, along the Oregon coast, USA $\left(43^{\circ} 13^{\prime} \mathrm{N}, 124^{\circ} 59^{\prime} \mathrm{W}\right)$.

Endoparasitoid stage: In the hemocoel and inside the abdomen and appendages of the host euphausiids.

Free-living encysted stage: Forming clusters of phoronts on filaments, not confirmed with scanning electron microscopy (SEM) observations, but likely associated with bacteria, as observed with $P$. brintoni (Gómez-Gutiérrez et al. 2012).

Type material: Two protargol-stained slides of $P$. oregonensis cells in the tomite stage (Holotype USNM 1084004 and Paratype USNM 1084005) and 1 Euphausia pacifica female in advanced stage of infection (23.7 mm total length, Non-type USNM 1084006) were deposited in the International Protozoan Type Slide Collection of the Department of Invertebrate Zoology of the National Museum of Natural History, Smithsonian Institution, by Gómez-Gutiérrez et al. (2006). We have now deposited a voucher slide (Fig. $3 \mathrm{D}, \mathrm{E})$ with cells of isolate 30 circled in black on the underside of the slide (USNM 1231430 [IZ]).

Gene sequences: Gene sequences of $P$. oregonensis were deposited in GenBank under accession numbers HQ591473 (SSU rRNA) and HQ591494 (cox1) for isolate 28; HQ591471 (SSU rRNA) and HQ591493 (cox1) for isolate 31, and HQ591472 (SSU) for isolate 30.

Pseudocollinia similis Lynn, Gómez-Gutiérrez, Strüder-Kypke, \& Shaw, 2014

Diagnosis: All life cycle stages possess 18-21 somatic kineties; tomite stage, ovoid with blunt anterior end; oral cavity bordered by 3 'oral' kineties; infecting a broadcast-spawning euphausiid distributed along the northeastern Pacific Ocean.

Type host: Thysanoessa spinifera Holmes, 1900

Other possible host: Thysanoessa gregaria G. O. Sars, 1883, but must be confirmed using gene sequences.

Type location: Northeast Pacific, along the Oregon coast, USA $\left(43^{\circ} 13^{\prime} \mathrm{N}, 124^{\circ} 59^{\prime} \mathrm{W}\right)$.

Endoparasitoid stage: In the hemocoel and inside the abdomen and appendages of the host euphausiids. 
Free-living encysted stage: Forming clusters of phoronts on filaments, not confirmed with SEM observation but likely associated with bacteria, as observed with P. brintoni (Gómez-Gutiérrez et al. 2012).

Type material: A protargol-stained slide of $P$. similis sp. nov. cells in the tomite stage (Holotype USNM 1231431 [IZ]) was deposited in the International Protozoan Type Slide Collection of the Department of Invertebrate Zoology of the National Museum of Natural History, Smithsonian Institution. The holotype (Figs. 3A,B \& 4B) as a cell from isolate 29 is circled in black on the underside of the slide.

Gene sequences: Gene sequences of $P$. similis sp. nov. were deposited in GenBank under accession numbers HQ591478 (SSU rRNA) and HQ591506 (cox1) for isolate 2 and HQ591485 (SSU rRNA) and HQ591492 for (cox1) isolate 29.

Etymology: The species name derives from similis (Latin meaning 'like, resembling') and is given because this species is the fourth described species of Pseudocollinia, which appears to be a complex of cryptic species of parasitoids infecting euphausiids of the northeastern Pacific Ocean.

Acknowledgements. We are indebted to Mrs. Christy Sherrard, who isolated, amplified, and sequenced the host mitochondrial cox1 genes at the Biodiversity Institute of Ontario (BIO). We acknowledge many researchers, graduate students, technicians, and ship support staff at Oregon State University and the University of Alaska Fairbanks for their help collecting zooplankton samples. We also thank the crews of the USCGC 'Healy,' the RV 'Knorr,' and the RV 'Thompson;' William T. Peterson and Alexei Pinchuk for the use of their plankton samples from Oregon and the Bering Sea; Edward Durbin for the loan of a Bongo net for 1 Bering Sea cruise; and Phillip Colla for the photograph of a healthy live Thysanoessa spinifera. This research was partially supported by the Instituto Politécnico Nacional, Centro Interdisciplinario de Ciencias Marinas (IPN-SIP 2013-2014), CONACyT 2012-C01-178615. J.G.G. was supported by an SNI fellowship, COFAA-IPN, and EDI-IPN grants. M.C.S.K. and D.H.L. were supported by an NSERC Canada Discovery Grant.

\section{LITERATURE CITED}

Capriulo GM, Small EB (1986) Discovery of an apostome ciliate (Collinia beringensis $\mathrm{n}$. sp.) endoparasitic in the Bering Sea euphausiid Thysanoessa inermis. Dis Aquat Org 1:141-146

Capriulo GM, Pedone MJ, Small EB (1991) High apostome ciliate endoparasite infection rates found in the Bering Sea euphausiid Thysanoessa inermis. Mar Ecol Prog Ser 72:203-204

Chantangsi C, Lynn DH, Rueckert S, Prokopowicz AJ, Panha S, Leander BS (2013) Fusiforma themisticola n. gen., n. sp., a new genus and species of apostome ciliate infecting the hyperiid amphipod Themisto libellula in the
Canadian Beaufort Sea (Arctic Ocean), and establishment of the Pseudocolliniidae. (Ciliophora, Apostomatia). Protist 164:793-810

Charleston MA (1998) Jungles: a new solution to the host/ parasite phylogeny reconciliation problem. Math Biosci 149:191-223

Conow C, Fielder D, Ovadia Y, Libeskind-Hadas R (2010) Jane: a new tool for the cophylogeny reconstruction problem. Algorithms Mol Biol 5:16

Cruaud A, Rønsted N, Chantarasuwan B, Chou LS and others (2012) An extreme case of plant-insect codiversification: figs and fig-pollinating wasps. Syst Biol 61:1029-1047

D'Amato ME, Harkins GW, de Oliveira T, Teske PR, Gibbons MJ (2008) Molecular dating and biogeography of the neritic krill Nyctiphanes. Mar Biol 155:243-247

Darriba D, Taboada GL, Doallo R, Posada D (2012) jModelTest 2: more models, new heuristics and parallel computing. Nat Methods 9:772

> De Rijk P, De Wachter R (1993) DCSE, an interactive tool for sequence alignment and secondary structure research. Comput Appl Biosci 9:735-740

> Du Toit N, Van Vuuren B, Matthee S, Matthee CA (2013) Biogeography and host-related factors trump parasite life history: limited congruence among the genetic structures of specific ectoparasitic lice and their rodent hosts. Mol Ecol 22:5185-5204

Felsenstein J (2009) PHYLIP (Phylogeny Interference Package) version 3.69. Available at http://evolution.genetics. washington.edu/phylip.html (accessed on 5 May 2014)

> Gómez-Gutiérrez J, Peterson WT, De Robertis A, Brodeur RD (2003) Mass mortality of krill caused by parasitoid ciliates. Science 301:339

> Gómez-Gutiérrez J, Peterson WT, Morado JF (2006) Discovery of a ciliate parasitoid of euphausiids off Oregon, USA: Collinia oregonensis n. sp. (Apostomatida: Colliniidae). Dis Aquat Org 71:33-49

> Gómez-Gutiérrez J, Strüder-Kypke MC, Lynn DH, Shaw CT and others (2012) Pseudocollinia brintoni gen. nov., sp. nov. (Apostomatida: Colliniidae), a parasitoid ciliate infecting the euphausiid Nyctiphanes simplex. Dis Aquat Org 99:57-78

> Guindon S, Gascuel O (2003) A simple, fast and accurate method to estimate large phylogenies by maximumlikelihood. Syst Biol 52:696-704

> Harvey HR, Pleuthner RL, Lessard EJ, Bernhardt MJ, Shaw CT (2012) Physical and biochemical properties of the euphausiids Thysanoessa inermis, Thysanoessa raschii, and Thysanoessa longipes in the eastern Bering Sea. Deep-Sea Res II 65-70:173-183

> Jarman SN (2001) The evolutionary history of krill inferred from nuclear large subunit rDNA sequence analysis. Biol J Linn Soc 73:199-212

> Johnson KP, Yoshizawa K, Smith VS (2004) Multiple origins of parasitism in lice. Proc R Soc Lond B Biol Sci 271: 1771-1776

Keller-Schmidt S, Wieseke N, Klemm K, Middendorf M (2011) Evaluation of host parasite reconciliation methods using a new approach for cophylogeny generation. Available at www.bioinf.uni-leipzig.de/working/11-013 (accessed on 5 May 2014)

> Kher CP, Doerder FP, Cooper J, Ikonomi P, Achilles-Day U, Kupper FC, Lynn DH (2011) Barcoding Tetrahymena: discriminating species and identifying unknowns using the cytochrome c oxidase subunit I (cox-1) barcode. Protist 162:2-13 
Kimura M (1980) A simple model for estimating evolutionary rates of base substitutions through comparative studies of nucleotide sequences. J Mol Evol 16:111-120

Kulka DW, Corey S (1984) Incidence of parasitism and irregular development of gonads in Thysanoessa inermis (Kroyer) in the Bay of Fundy (Euphausiacea). Crustaceana 46:87-94

Kuo CH, Wares JP, Kissinger JC (2008) The Apicomplexan whole-genome phylogeny: an analysis of incongruence among gene trees. Mol Biol Evol 25:2689-2698

Merkle D, Middendorf M, Wieseke N (2010) A parameteradaptive dynamic programming approach for inferring cophylogenies. BMC Bioinformatics 11(Suppl 1):S60

Montagnes DJS, Lynn DH (1993) A quantitative protargol stain (QPS) for ciliates and other protists. In: Kemp PF, Sherr BF, Sherr EB, Cole JJ (eds) Handbook of methods in aquatic microbial ecology. Lewis Publishers, Boca Raton, FL, p 229-240

Przyboś E, Tarcz S, Dusi E (2013) New Paramecium quadecaurelia strains ( $P$-aurelia spp. complex, Ciliophora) identified by molecular markers (rDNA and mtDNA). Eur J Protistol 49:477-486

Ronquist F, Huelsenbeck J (2003) MrBayes 3: Bayesian phylogenetic inference under mixed models. Bioinformatics 19:1572-1574

Rosenblueth M, Sayavedra L, Sámano-Sánchez H, Roth A,

Editorial responsibility: Rebecca Gast,

Woods Hole, Massachusetts, USA
Martínez-Romero E (2012) Evolutionary relationships of flavobacterial and enterobacterial endosymbiont with their scale insect hosts (Hemiptera: Coccoidea). J Evol Biol 25:2357-2368

Saitou N, Nei M (1987) The neighbor-joining method: a new method for reconstructing phylogenetic trees. Mol Biol Evol 4:406-425

Shimodaira H (2002) An approximately unbiased test of phylogenetic tree selection. Syst Biol 51:492-508

Shimodaira H, Hasegawa M (2001) CONSEL: for assessing the confidence of phylogenetic tree selection. Bioinformatics 17:1246-1247

Stamatakis A, Hoover P, Rougemont J (2008) A rapid bootstrap algorithm for the RAxML web-servers. Syst Biol 57: 758-771

Strüder-Kypke MC, Lynn DH (2010) Comparative analysis of the mitochondrial cytochrome $C$ oxidase subunit I (COI) gene in ciliates (Alveolata, Ciliophora) and evaluation of its suitability as a biodiversity marker. Syst Biodivers 8:131-148

Swofford DL (2002) PAUP* ${ }^{*}$ phylogenetic analysis using parsimony, 4.0b10. Sinauer, Sunderland, MA

Tamura K, Peterson D, Peterson N, Stecher G, Nei M, Kumar S (2011) MEGA5: molecular evolutionary genetics analysis using maximum likelihood, evolutionary distance, and maximum parsimony methods. Mol Biol Evol 28:2731-2739

Submitted: March 17, 2014; Accepted: July 28, 2014

Proofs received from author(s): November 5, 2014 